rator). Trois autres proboscidiens ont vécu dans l'Amérique du nord pendant la période post-pliocène ou quaternaire; ce sont l'Elephas Americanus, que M. Leidy considère comme étant distinct de l'E. primigenius, l'E. Columbi, Falc., des Etats du Sud et du Mexique, et le Mastodon Ohioticus, que quelques auteurs supposent avoir été contemporain des premiers hommes qui se sont établis dans cette région du globe." Whilst, how ever, I decline to offer any opinion whether the tooth figured by Meek may be referable to the $E$. imperator of Leidy, from Niobrara, I copy Dana's woodeut in the margin.

I have previously and frequently expressed the utmost deference to the palæontological authority of Dr.Falconer, whose constant study of the fossil specimens, thorough knowledge of the habits and food of the existing Indian elephant, and exhaustive aequaintance with proboscidean bibliography, must command respect amongst comparative anatomists. The foregoing remarks have, however, been called for to re-assert my title to be the first who directed attention to the "Bollaert molar," and to claim the undoubted privilege of every scientific man to deseribe any species of which no full, complete, and accurate definition has been previously promulgated. Yours truly,

C. Carter Blake.

\title{
BDituary Krotice.
}

\section{LUCAS BARRETT, F.G.S.,}

DIRECTOR OF THE GEOLOGTCAI SURVEY OF THE BRITISII WEST INDINS.

THE last West India mail brought letters and papers announcing the premature loss of this amiable and accomplished naturalist, so lately among us taking an active part in the proceedings of the British Association at Cambridge.

He left England on the 17th of October last, and returned to Jamaica, accompanied by $\mathrm{Mr}$. W. P. Colchester, eldest son of the gentleman who has for some years been the contractor for all the fossil phosphates of the Crag district and Cambridgeshire. He had formerly made a few very promising dredgings on the coast, at considerable deptlis; and being anxious to explore those portions of the sea-bed (between low-water and the limit of coral-perhaps about 15 fathoms) which are inaccessible to the dredge, he took out with lim a diver's dress and pumping apparatus of the most approved construction, such as Mr. Heinke lias supplied to all the stations of the Peninsular and Oriental Company, and which has been so successfully employed in recovering the wrecks of the 'Malabar,' 'Colombo,' and 'Royal Charter.' Dr. Bowerbank, of Kingston, writes word that he met Mr. Barrett on the 18th December last, in the House of Assembly, where he had gone to give evidence before a committee. He then told Dr. B. that he had been down the day before (in his diving-dress) in shallow water, and had succeeded well, and intended trying deeper water for the purpose of examining the coral reefs. Dr. Bowerbank begged him to wait till he could go with him ; but he replied that " he would see." Other friends also warned him not to go, and offered to accompany him if he would defer it for a day ; but he went, attended only by the boat's crew of negroes and his (negro) servants. Mr. Colchester happened to be away at the time, at the Pedro Keys. He says that " according to the evidence given by the men, Mr. Barrett went direct 
down from the boat into deep water by means of a rope-ladder. The pumps were worked uninterruptedly, as on the former occasion; but they noticed that he remained below longer than previously (which, according to his own statement, had been half an hour), and suddenly, to their horror, they observed his body floating at the surface of the water, a little distance from the boat. They got to him as quickly as possible, without ceasing pumping (so they declare), and on the removal of the helmet found him apparently dead. Without knowing in the least what to do, they took him on shore-some distance; but, of course, it was all orer then, if it had not been long before." 'The verdict, at the inquest, made it appear that water had got in to the air-tube at the joint, which was not screwed up tight enough ; but this Mr. Colehester (and also Mr. Heinke) regarded as impossible. No water seems to have been found in the dress; and the rising to the surface, with all the weights npon him, conld only have oceurred by the valves for the escape of the air being closed. There is a small eseapevalve in the helmet which is closed by a spring, and does not act until the pressure of the air is more than sufficient to cause the diver to rise. The principal valve is in the breast of the dress, and is closed by a lever, requiring the action of the hand. Now it appears that Mr. Barrett had neglected the precaution (which is always made imperative) of attaching the life-line to his body, preferring, he said, to hold it in his hand. If by any chance he lost this rope, he would lose his means of communicating with the erew, and become entirely dependent on the air-tube. His only means of rising to the surface would be by closing the escape-valve, which he must have done for this purpose, perhaps, on finding that something had gone wrong. All the inquiries hitherto made have left a painful doubt, which time will scarcely remove.

It has appeared desirable to give these particulars, becanse it looks like an instance of self-reliance carried too far, and a valuable life sacrificed, apparently, by the necrlect of those precautions which any one less daring would have observed. 'The divers professionally employed work four hours at a spell, often inside the hulls of vessels; they are said even to have gone to sleep below! The only casualties have been one or two apoplectic seizures, which have occurred to men in government works, who probably were not fitted for the occupation.

Lucas Barrett was born in London, November 14, 1837. He was the eldest son of Mr. George Barrett, the iron-founder, whose works at the Record-Office and King's Cross Terminus are well known. He was sent, in 1847, to Mr. Ashton's school, at Royston, Cambridge, and afterwards to University College School, and in lis holidays used to visit the British Museum, where he soon became known to the Natural History officers, by bringing fossils to be named, and volunteering to assist in unpacking and sorting collections. In 1853, he went to Ebersdorf, near Lobenstein, Voigtland, where he remained a year studying German and chemistry; and making, in the course of it, a pedestrian tour in Bavaria, which deserves to be recorded, as having cost him only one shilling a day. In 1855, he accompanied Mr. M'Andrew in a yachting royage to Norway and Finmark, and made some observations on the living Terebratula, which were published in the Ann. Nat. Hist., and translated into the scientific journals of France and Germany. The same year he was chosen successor to $\mathrm{Mr}$. M.Coy, as Curator of the Cambridge University Museum, and was elected a Fellow of the Geological Society of London, although perhaps legally ineligible, being only eighteen years of age. In the following year he obtained leave of absence, and accompanied Mr. J. W. Tayler to Greenland,--an expedition attended with considerable 
expense and no small amount of hardship, of which no account has been published; but there is a suite of specimens of shells, etc., collected by him, in the British Museum. In 1857, he again accompanied Mr. M'Andrew in a voyage to Vigo (the last cruise of the ' $N$ aiad'), and added extensively to his collection of Eelinodermata. Still, nothing was published except a short communication (by himself and Mr. Woodward), in the Proceedings of the Zoological society, on the gencra synapta and Cheirodota.

During his custody of the Cambridge Geological Museum, many considerable additions were made and arranged by Mr. Barrett: such as the Saurians from the Lias, presented by Mr. I'. Hawkins; the beautiful collection of Chalk fossils bequeathed by Dr. Forbes Young; and the local collection of the Rer. 'T. Image. 'The rapid and extensive development of the use of fossil phosphates from the Upper Greensand around Cambridge, supplied him with a new field of research; and early in 1858 he had detected two bird-bones, and numerous remains of several distinct species of Pterodactyle (some of extraordinary size), which have been figured and described by Professor Owen in the Transactions of the Palæontographical Society. He had also prepared a geological map of the vicinity of Cambridge, of which a second edition was published (by Macmillan) in the last year.

In 1859 , he was appointed by Sir H. Bulwer to the important post of Director of the Geological Survey of the British West Indies, chicfly, it is understood, upon the recommendation of Professor Phillips. 'The salary and allowance for expenses, $£ 700$ a year, was raised to $£ 800$ soon after he had commenced his duties; and the sphere of occupation opened to him was every way worthy of his versatile and enterprising genius. 'The number of the 'Geologist' for last October contains a figure and description of a marvellous fossil discovered by him in Jamaica, and named after him, very much against his wish.

But although so well occupied in Jamaica, he must have retained a strong regard for Cambridge, where so much of his young life was passed. $\mathrm{He}$ had frequently lectured for Professor Sedgwick, and was such a favourite, that had he been a little older, and a graduate of the University, he would have been regarded as the probable successor to the Geological Chair. Some time before leaving England he was persuaded to enter Trinity College; and last year, when he came over as Commissioner for Jamaica to the International Exhibition, he resided and kept his Terms at Cambridge.

Of all the younger naturalists of the day he approached most nearly to Professor E. Forbes, in the sweetness of his disposition, his instinctive good taste, and the brightness of his intelligence; inferior, however, to Forbes in two respects, inasmuch as he never showed an aptitude for public speaking or writing. It may have existed in him, and would possibly have developed itself, had his life been spared. As it is, he served but for a little space to hold the lamp of science committed to him by some who trusted that he would long continue to hand onward that glorious light when they should have passed away.

S. $\stackrel{\text { P. W. }}{\text { W. }}$

\section{FOREIGN INTELLIGENCE.}

The topographical survey of Spain, under M. Coello, the aceomplished geographer, is making progress. The triangles of the first order have 